\title{
Traditional knowledge and processes of innovation and creativity: Brazilian pottery and bobbin lace makers
}

\author{
Marinilse Netto \\ Doutoranda do Programa de Pós-Graduação em Engenharia e Gestão do Conhecimento da \\ Universidade Federal de Santa Catarina, Florianópolis, Santa Catarina, Brasil. \\ Mari.netto@hotmail.com
}

Francisco Antonio Pereira Fialho

Doutor em Engenharia de Produção, Engenharia do Conhecimento.

Professor da Universidade Federal de Santa Catarina, Florianópolis, Santa Catarina, Brasil.

fapfialho@gmail.com

\begin{abstract}
Using a qualitative approach, this article sets out to clarify how innovation and creativity are changing the customs in two traditional Brazilian communities: the pottery makers of Goiabeiras, of the city of Vitória, Espírito Santo, and the bobbin lace makers in Florianópolis, Santa Catarina. Primary data from observation and semistructured interviews with pottery makers, lace makers and agents from public institutions responsible for the projects in the communities were used. Secondary data sources, derived from digital documentary analysis (websites) were also used. In order to analyze the data, the research uses methodological triangulation with two categories: tradition (maintenance) and resources and innovation (its discourse elements). The study shows that to remain in their communities, these people use the knowledge of their ancestors to create sustainable livelihood strategies and income generation.
\end{abstract}

Key words: cultural artifacts, income generation, preservation of knowledge, traditional communities, traditional knowledge.

\section{Introduction}

Changes in technology and the acceleration of urbanization processes spanning the late nineteenth century engendered new societal demands. Consequently, society saw significant changes in peoples' habits, values and behaviors. Even communities that remained relatively autonomous were disturbed by these developments. The particular modes of organization and survival of challenged these traditional populations and their increasing urban dependence modified some of their interests and their own culture.

The effect is particularly noticeable in younger generations that are more sensitive to "external" influences. Influences cause disruptions in a community's traditional ways of maintaining and attributing meaning to shared knowledge between generations. We stress that the conditions of segregation and devaluation suffered by these populations "forced" members to find new ways of living and adapting to inclusion in a globalized society. 
In this study, we investigated how tradition and innovation are reconciled in two communities: 'Rendeiras da Lagoa da Conceição' (lacemakers) in Florianópolis, Santa Catarina, and 'Paneleiras de Goiabeiras' (potters) in Vitoria, Espírito Santo, Brazil. Members of these populations entered into new social relationships by 'lending' their unique techniques to the development of artifacts (bobbin lace and traditional pottery) for commercial consumption by the tourism industry.

By choosing two geographically distant communities with different scenarios, we examined the similarities and differences between the two contexts. It was not our intention to compare the quality of the products or to generalize about issues concerning production processes, aesthetics, value or marketing issues.

\section{Traditional populations and their knowledge}

Traditional Knowledge (TK) is locally developed knowledge that has been in a culture or society that members of the community receive as an inheritance from their ancestors. It involves creativity, innovation and skills (Sukula, 2006). Moreira (2007) described TK as the oldest form of preserving theories, experiences, concepts and rules; it is the most ancient form of developing scientific knowledge. Busingye and Keim (2009) described TK as orally transmitted knowledge, elaborated throughout generations, through practical trial and error experiences. Perelli (2008) suggested that TK is what defines a traditional population.

The erosion of TK, understood as its transformation or loss, is globally recognized (Kumari, 2003; Alexander et. al., 2004; Kothari, 2007).This situation is due, in large part, as primarily tacit knowledge, being passed down from generation to generation (Brahy, 2006). This process hinders its encoding, recording and consequently its preservation. Canclini (2003, p. 215) stated that, among the studies of Latin American populations, that "many show that in recent decades traditional cultures have been evolving through transformation", ${ }^{1}$ hybridizing themselves.
Cultural production linked to media emphasis regarding the development of tourism, internal migration and the increasing secularization of our society are providing individuals with a variety of cultural options, both religious and spiritual, which can disrupt the dominant aesthetic or symbolic models in many traditional cultural expressions. The accelerated urbanization of our major population centers in recent decades, bringing with it new forms of social interaction is also common amongst other Latin American countries (Carvalho, 1991). Culturally different groups that historically reproduce their way of life in more or less isolated settings characterize traditional populations. This notion refers to indigenous peoples as population segments that develop particular ways of life, well adapted to specific ecological niches (Castro, 1998).

In Brazil, the decree $N^{\circ}$ 6040, February 7, 2007, which defined Traditional Peoples and Communities as (Brasil, 2007):

culturally differentiated groups who recognize themselves as such. They have their own forms of social organization. They occupy and use territories and natural resources as conditions for their cultural, social, religious, ancestral and economic replication, using knowledge, innovation and practices generated and transmitted by tradition. ${ }^{2}$ (Article 3, Section I)

Examples of traditional peoples include indigenous, "quilombolas" and "caiçaras", riverine communities and artisan fishermen communities, among others. These communities occupy settings rich in natural resources, on a mostly subsistence basis, and are weakly linked to markets. They use family intensive labor practices and low-impact technologies derived from traditional knowledge, and are generally sustainable (Arruda, 1999). Unesco - the United Nations Educational, Scientific and Cultural Organization defined this process on its homepage in 2010, as:

Practices, representations, expressions, knowledge and techniques - along with the tools, objects, artifacts and cultural sites associated with them which communities, groups and, in certain cases, individuals recognize as an integral part of their cultural heritage. ${ }^{3}$

\footnotetext{
1. Tradução dos autores, do original: "muitos estudos revelam que nas últimas décadas as culturas tradicionais se desenvolvem transformandose" (Canclini, 2003, p. 215).

2. Tradução dos autores, do original: "Povos e Comunidades Tradicionais: grupos culturalmente diferenciados e que se reconhecem como tais, que possuem formas próprias de organização social, que ocupam e usam territórios e recursos naturais como condição para sua reprodução cultural, social, religiosa, ancestral e econômica, utilizando conhecimentos, inovações e práticas gerados e transmitidos pela tradição" (BRASIL, 2007).

3. Tradução dos autores, do original: "Práticas, representações, expressões, conhecimentos e técnicas - junto com os instrumentos, objetos, artefatos e lugares culturais que Ihes são associados - que as comunidades, os grupos e, em alguns casos, os indivíduos reconhecem como parte integrante de seu patrimônio cultural" (UNESCO, 2010).
} 


\section{Bobbin Lace Makers from Lagoa da Conceição - Florianópolis, Santa Catarina, Brazil}

The presence of bobbin lacemakers and their location on the Brazilian coastline is closely linked to fishing activities. A Brazilian proverb states, "where there are bobbin lacemakers, there is income". Lagoa da Conceição, a beautiful salt lake adjacent to the city of Florianópolis, has been an epicenter of Azorean culture since the colonization of the island of Santa Catarina in 1748. The knowledge that involves bobbin lace production is a traditional element of material culture of Azorean - Portuguese immigrants.

Colored cushions, stuffed with grass, paths drawn on bobbins (paper printed with patterns) are represented. Patterns that make up the different types of lace designs include; "Maria the Brunette", "Cocada" (a reference to a macaroon-like coconut biscuit), and "Starry Sky", among others. The "Tramóia", or a malicious plot, is one of the most frequently used patterns in the manufacture of tray cloths and towels. All patterns are considered traditional features.

The Bento Silvério Cultural Center, known as the "Big House" of the bobbin lacemakers is appropriately located within the central area of the district. Here, space is dedicated to the preservation and dissemination of this traditional knowledge, and people from different places are welcomed and taught bobbin-lace techniques. Since March 2011, the coordination of activities has been under the auspices of the Franklin Cascaes Cultural Foundation, which provided municipal resources to participating groups in a Program Known as the "Program for the Promotion of Traditional Cultural Handicrafts", or PROMOART. PROMOART aims "to create a market that recognizes the value of traditional crafts in the contemporary world". The Anthropology Department at the Federal University of Santa Catarina and UDESC Fashion School are also involved in the preservation and dissemination of bobbin-lace techniques.

\section{Artisan potters of the Goiabeiras district - Vitória, Espírito Santo, Brazil}

Pottery made in the Goiabeiras district constitutes a 400-year-old functional tradition, and the area has been a tourist attraction since the early 1800 s. The techniques used to produce the pottery are of indigenous heritage and recognized both nationally and internationally as a form of folk art. Not only is the pottery an art form, it also serves a functional tradition, and is widely utilized in regional cuisine.

Known as "Old Goiabeiras", the neighborhood continues to be the foundation of this ancient occupation. Through a cultural project, the City of Victoria, and other Federal Institutions such as IPHAN and SEBRAE have taken actions to preserve and disseminate the production process. For example, the construction of a new workspace, dubbed the "Pottery Shed" and creation of the Registry Office of Intangible Heritage are listed in the 2002 Book of Knowledge; products which contain the Seal of Quality of the "Paneleiras Goiabeiras" Association and an indication of origin, ensuring purchasers of the authenticity of the products.

After completing official documentation, IPHAN promotes the protection and monitoring of "cultural property" in order to improve the infrastructure, dissemination and appreciation of the community that maintains and preserves such property. Only after ten years of documentation in the Book of Knowledge did IPHAN begin to issue qualification and approval certificates. The "Paneleiras Goiabeiras" received the title on July 7, 2013, which marks the official celebration date of "Paneleiras Goiabeiras".

All of the Paneleiras Shed activities are managed by the Paneleiras Association, which receives financial assistance from public and private entities, such as the Federal University of Espírito Santo, INFRAERO, and the Federal Savings Bank among others.

\section{Innovation, tradition and creativity}

Tradition and innovation is understood as a notion that originates from diverse domains, each with its own logic, rules of operation, viability and legitimacy. We understand innovation as new ideas, goods, services, practices or production that would be useful (Bruce and Bessant, 2002), including the concepts of innovation, commercialization and/or implementation (Popadiuk, 2006). In this context, innovation is defined as a social phenomenon that occurs within a "value network", understood as a system of value creation in which different actors collaborate. In this sense, innovation is primarily an interactive process in which several agents converge in innovative effort. There can be no sustainable progress of social inclusion without continuous innovation processes (Comissão, 2009).

Freeman and Pérez (1988), divide innovation into four categories: (1) gradual or incremental - how small changes accumulate and can provoke significant effects; (2) radical - represents the kind of innovation that is supported by a systematic and institutionalized effort by large corporations, which, strictly speaking, 
has sustainable financial and technological resources; (3) changes in the technological system - progressive and radical innovations that structurally affect the context, changing the status quo, and (4) changes in the techno-economic paradigm - a set of interrelated innovations capable of redefining not only the context, but also the paradigm and the underlying structure of the current model.

When we talk about tradition, we think of the formalization of perennial practices and behaviors that are perpetuated through repetition. However for Giddens (1991, p. 80) tradition "is a means of organizing collective memory and traditional phenomena" which becomes "the multi-determined product of popular and hegemonic, rural and urban, local, national and transnational agents"4 (Canclini, 2003, p. 220). Tradition, in this sense, is understood as a continuum "without any break with the past, but is in fact built on it" (Benjamin, 1996, p. 7). For Marques (2004, p. 34) "no matter how well placed a community is, there are always echoes reverberating from other cultures and other life experiences." ${ }^{\circ}$

According to Marques (2004, p. 30) when situated in close proximity to tourism, traditional culture or folklore can be thought of as complementary,

Under certain conditions and in certain contexts this situation can create opportunities for positive interaction, as the "goal is to grow, perpetuate itself, or even in times of high competition, to survive. This does not mean, of course, that tradition must be abandoned."

Folklore has long been associated with an oral conservationist tradition, linked to collective memory. It is considered the result of an identity formed within a local culture which should be kept pure and unchanged. Tourism, on the other hand, appeared as one of the most visible effects of capitalist industrial development, driven by market logic and coupled to the cultural industry.7 (Marques, 2004, p. 30)
Tourism initiatives have provided populations with new ways of social insertion and livelihood. As indicated by Canclini (2005) in times of globalization, changes in artisans craft production are necessary for a group to stay organized and in some way, remain tied to their traditions.

The main results of this compromise are the increasing income through diversification in production processes, and the dissemination of traditional work, previously restricted to local areas. In this respect, tradition suffers a slow, continuous adjustment of context, and is constantly being reinvented.

[W] hen a rapid transformation of society weakens or destroys the social patterns for which 'old' traditions had been designed, producing new ones to which they were not applicable, or when such old traditions and their institutional carriers and promulgators no longer prove sufficiently adaptable and flexible, or are otherwise eliminated:in short, when there are sufficiently large and rapid changes on the demand or the supply side. ${ }^{8}$ (Hobsbawm and Ranger, 1984, p. 13)

In this reinvention process there are strong internal (intrinsic) and external (extrinsic) stimuli, which in this sense can be best understood through the "Componential Model of Amábile" (1983, 1989, 1996), which seeks to show how cognitive, motivational, social and personality factors influence the creative process.

According to Amábile, social motivations place great emphasis on creativity. She suggests that the development of creative processes is based on three components: skills mastery in a domain, relevant creative processes, and intrinsic motivation. Amábile (1996, p. 119) stated, "intrinsic motivation leads to creativity; controlling extrinsic motivation is harmful to creativity, but informative extrinsic motivation can lead to creativity, particularly if there are high initial levels of intrinsic motivation."

\footnotetext{
4. Tradução dos autores, do original: "são hoje o produto multideterminado de agentes populares e hegemônicos, rurais e urbanos, locais, nacionais e transnacionais" (Canclini, 2003, p. 220).

5. Tradução dos autores, do original: "sem uma ruptura com o passado, mas que se constrói sobre esse passado" (Benjamin, 1996, p. 7).

6. Tradução dos autores, do original: "Esquecendo que, por mais localizada que esteja uma comunidade, nela se repercutem sempre os ecos de outras culturas e de outras experiências de vida" (Marques, 2004, p. 34).

7. Tradução dos autores, do original: "O folclore foi durante muito tempo associado a uma tradição oral conservadora, ligada à memória coletiva, fruto da formação identitária de uma cultura local que deveria ser mantida pura e inalterada, ao passo que o turismo apareceu como um dos efeitos mais visíveis do desenvolvimento industrial do capitalismo, gerido de acordo com a lógica do mercado, associado à indústria cultural" (Marques, 2004, p. 30).

8. Tradução dos autores, do original: "[...] quando uma transformação rápida da sociedade debilita ou destrói os padrões sociais para os quais as "velhas" tradições foram feitas, produzindo novos padrões com os quais essas tradições são incompatíveis; quando as velhas tradições, juntamente com seus promotores e divulgadores institucionais, dão mostras de haver perdido grande parte da capacidade de adaptação e da flexibilidade; ou quando são eliminadas de outras formas. Em suma, inventam-se novas tradições quando ocorrem transformações suficientemente amplas e rápidas tanto do lado da demanda quanto da oferta" (Hobsbawm; Ranger, 1984, p. 13).
} 
Table 1 - illustrates the interdependencies between domain skills, creativity, and motivation or incentives for activity development.

\begin{tabular}{|c|c|c|}
\hline DOMAIN SKILLS & CREATIVITY SKILLS & TASK MOTIVATION \\
\hline \multicolumn{3}{|c|}{ INCLUDE } \\
\hline $\begin{array}{l}\text { - Domain knowledge } \\
\text { - Technical skills required by the } \\
\text { domain } \\
\text { - Special skills required }\end{array}$ & $\begin{array}{l}\text { - Cognitive style } \\
\text { - Implicit (tacit) or explicit knowledge of } \\
\text { heuristics for the generation of new ideas } \\
\text { - Compatible working styles }\end{array}$ & $\begin{array}{l}\text { - Attitudes toward the tasks } \\
\text { - Perception motivation to perform } \\
\text { the task }\end{array}$ \\
\hline \multicolumn{3}{|c|}{ DEPEND ON } \\
\hline $\begin{array}{l}\text { - Cognitive skills } \\
\text { - Motor and Perceptual skills } \\
\text { - Formal and informal education }\end{array}$ & $\begin{array}{l}\text { - Training } \\
\text { - Experience in generating ideas } \\
\text { - Personality characteristics }\end{array}$ & $\begin{array}{l}\text { - Initial level of intrinsic motivation } \\
\text { with respect to the task } \\
\text { - Presence or absence of significant } \\
\text { extrinsic barriers } \\
\text { - Ability to minimize individual } \\
\text { extrinsic "cognitively obstacles" }\end{array}$ \\
\hline
\end{tabular}

Adapted from Amábile (1996)

According to Alencar and Fleith (2003, p. 5) "even though the model proposed by Amábile (1996) mainly includes intra-individual components, the environment exerts a crucial influence on each of them, at all stages of the creative process." 9 The process of adaptation performed in traditional artifact production described in this model is shown below, in Figure 1.

According to UNESCO $(2010$, p.5) all creativity originates in cultural traditions, however it only flourishes in contact with other cultures and people. For this reason heritage in all its forms must be preserved, enhanced and handed on to future genera- tions "in order to foster creativity, in all its diversity, establishing a genuine dialogue among cultures."

\section{Method}

The research is qualitative in character, with participant observation and semi-open interviews taking place in July and August of 2012. The individuals researched include 35 potters, 10 lacemakers and 2 cultural agents. The four individuals who participated in the interviews included two potters and

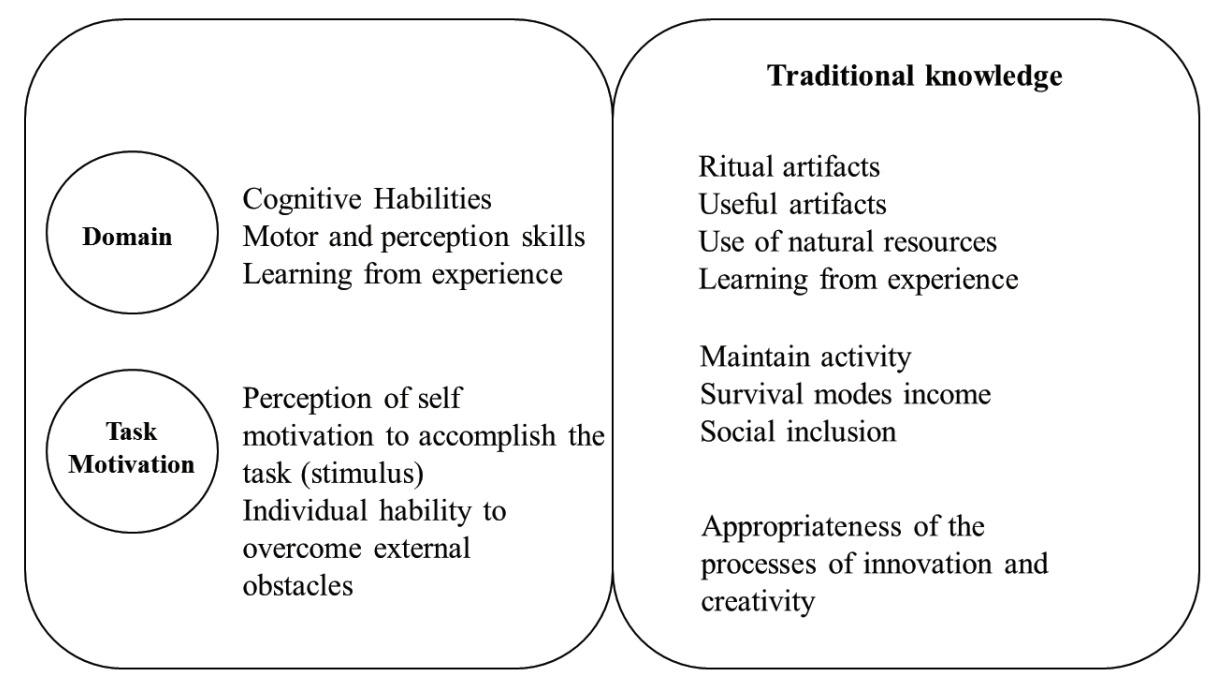

Figura 1 - Behavioral components necessary to adapt traditional techniques

\footnotetext{
9. Tradução dos autores, do original: "Embora o modelo proposto por Amábile (1996) inclua predominantemente componentes intra-individuais, o ambiente exerce influência crucial sobre cada um deles em todas as etapas do processo criativo" (Alencar; Fleith, 2003, p. 5).

10. Tradução dos autores, do original: "Toda criação tem suas origens nas tradições culturais, porém se desenvolve plenamente em contato com outras. Essa é a razão pela qual o patrimônio, em todas suas formas, deve ser preservado, valorizado e transmitido às gerações futuras como testemunho da experiência e das aspirações humanas, a fim de nutrir a criatividade em toda sua diversidade e estabelecer um verdadeiro diálogo entre as culturas" (UNESCO, 2010, p. 5).
} 
two lacemakers, chosen by the community based on ability and experience. We developed a rough guide questionnaire, used as a point of departure to begin the interviews. This approach allowed us to establish an intimate tone with the participants (Creswell, 2010).

We asked the informants to tell us their life stories (storytelling), who taught them to make pottery or bobbin lace, as well as their motivation in continuing to work with those products. During the interviews, we inquired about their names, ages, and time spent developing their craft. We also questioned them about their knowledge of ancestral production methods, and the degree to which those methods differ from the methods they currently employ. Upon concluding the interviews, we asked how they felt about the space they work in, whether they believe their knowledge is valued, and how they relate to the cultural agents of their respective municipal governments.

The semi-open interviews with cultural agents (officials from departments of culture related to municipal governments) were aimed at learning about the management models employed by such governments and how they relate to the perspectives and challenges within the various artisan communities. The primary data collection method was carried out by the researcher on a personal basis, in places where the participants work, because the data makes sense in the context of field research (Gil, 2010, p. 119). The participants were informed of the purpose and structure of the research and presented with a "Statement of Consent", in order to highlight the voluntary nature of participation in the study.

The primary data collected in narratives and interviews was analyzed along with information contained in documents available on the website of the Municipal Office of Florianópolis and the Association of Goiabeiras Potters, through methodological triangulation, which provided a survey of two categories of analysis: Tradition, its maintenance and characteristics, as well as innovation and its elements of discourse.

\section{Results}

Production methods are changing. Tradition through innovation turns artifacts into more than symbols of the past where new possibilities of culture, valuation and economic factors affect the work.

Changing or mixing with innovations has advantages and disadvantages (Canclini, 2003). Despite the inevitable disruption of the status quo, the TK approach to the field of innovation allows traditional communities to adapt to new realities. Lace, pottery, baskets, and ceramics become valued beyond their area of origin, undergoing modifications according to consumer criteria. In addition, the production processes of artifacts tend to vary. However, traditional artifacts are no longer perceived as relics of the past. Possibilities for processes that lead to the appreciation and promotion of cultural economies become possible.

A thorough analysis of participant responses yielded the following categories or themes: (1) Tradition, innovation and its contradictions; (2) Creativity, skills and motivations and; (3) Modernity, elements of speech.

\section{Tradition, Innovation and its contradictions}

The artifacts produced by traditional populations are categorized as progressive, or incremental, innovation. As mentioned earlier, Freeman and Perez (1988) indicate that small changes, as they accumulate, can generate significant effects, causing major changes both in the production process and in final products.

By asking participants about the origin of their actions, it was apparent thatboth cultural heritage and economic survival played a part. Participant C.I1 learned make pottery with a neighbor and felt encouraged enough to sell his first pieces.

[1] "I'm so happy that I'm [...] still making pottery. And I've been making pots for 20 years." (C.I1)

[1] "Estou tão feliz que eu [...] continuo fazendo panela até hoje né? E tá com 20 anos que eu faço panela." (C.I1)

[2] "long ago pottery was made to help out your husband. [...] Life was tough then and few people bought them." (C.I2)

[2] "[...] se fazia panelas antigamente era pra ajudar um pouco o esposo né? Porque era muito difícil a vida antigamente e era poucas pessoas que compravam." (C. I2)

Similarly, participant C.I2 described how she learned by observing her aunt and older sisters make pottery in their backyard, [3] "[...] once [...] when my aunt was fed up of seeing us just playing, my niece, who was her granddaughter and myself, she started to teach us. Then we got interested. From then on I started to earn a little money, and my niece and I started to like it". 
[3] “[...] aí uma certa vez, ela (a tia) cansada de ver a gente só brincando, eu e a minha sobrinha, que é neta dela, começou a nos ensinar. Nisso o interesse foi crescendo. Daí em diante eu comecei a ganhar meu dinheirinho, eu e minha sobrinha começamos a gostar."

While the fishermen were at sea, the women devoted themselves to housework, child care and lace making [4] "[...] even though it wasn't much, they used it as an extra bit of income" (A.I4). For another participant, now an elderly bobbin lacemaker, learning began at an early age.

[4] “[...] pouco ou não, mas elas também usavam como fonte de renda." (A.I4)

[5] “I'm 81, I started making lace at 7, because my father abandoned my mother, leaving me and my two brothers; my brothers were 15 and 13 years old [...] they were already going out fishing [...] I was making Portuguese lace with my mother to support us at that time." (L.I5)

[5] "Eu to com 81, comecei a fazer com 7 anos, porque meu pai separou-se da minha mãe aí ficou eu e dois irmãos, aí, meus irmãos com 15-13 anos[...] já iam pescar [...]eu ia fazer renda portuguesa com minha mãe pra sustentar nós naquele tempo." (L.I5)

These statements revealed that instruction took place in different spaces and environments, divergent from activities within the family, the community or elsewhere, and that for potters, in the form of workshops for teachers and university academics. The former response is similar to formal models of teaching and professionalism. In the "Big Lacemakers' House" on the annual calendar, there are meetings, space for artisans from different riverine locations to exchange experiences and workshops for artisans interested in generating extra income through other handicraft activities".

[6] "I've taught, I’ve already given several workshops and I've a sister-in-law who says when she gives an interview that she learned everything from me [...] her pottery is really beautiful. I think it's even more beautiful than mine, [...] I've given several workshops here in schools, and one that was paid by the government to give to teachers in the community, so some clay pottery-makers are members here because they learned in the first workshop we gave them more than 25 years ago.” (C.I2)

[6] "Já ensinei, já dei várias oficinas e tenho uma cunhada, que quando ela dá entrevista ela fala pra qualquer um que aprendeu comigo [...] as panelas dela são muito bonitas, eu até acho que até mais bonito que as minhas [...] dei várias oficinas aqui pra escolas, e uma que o governo pagou para nós darmos para professoras da comunidade, então tem algumas paneleiras que são associadas aqui porque aprendeu nessa primeira oficina que nós começamos a dar, a mais de 25 anos atrás.” (C.I2)

[7] "I've taught nieces, cousins, and three girls over there in São José” (L.I5)

[7] "Já ensinei pra sobrinha, pra prima, pra três moça lá de São José.” (L.I5)

Regarding the production and major modifications, one of the participants (C.12) noted that in the past small amounts of pottery was produced, mostly for communal and regional use. We highlight below some responses that identify changes in the artifact production process.

[8] "The way they made pottery is not like the way we make it now [...] they used to sit on the ground and hold the pot, like this, between their legs [...]."(C.I1)

[8] "O jeito que eles faziam panela não é como que a gente faz agora [...] eles ficavam sentados no chão, né, botavam a panela assim no meio das pernas assim." (C.I.1)

[9] "At that time we only worked with fine thread. It was only later that there was thick thread, and colored thread [...] at that time there were only spools of thread 24." (L.I5)

[9] "Naquele tempo que a gente fazia só com linha fina, depois é que veio a linha grossa, a colorida [...] naquele tempo era aquela de carretel 24.” (L.I5)

[10] "I think, it's quicker now, you know why? Because in the past they left the pots to really bake, in order to smooth them off. They say it was terrible then. They wanted the pots to be really dry for smoothing off. It's different now. We smooth then off before baking." (C.IE1)

[10] "Eu acho que agora, é mais rápido, sabe por quê? Porque antigamente eles botavam deixavam torrar mesmo a panela, pra ficar bem torrada pra alisar, diz que era coisa horrível, antigamente, diz que eles queriam eles queriam a panela bem sequinha pra alisar, agora não, alisa antes de queimar." (C.IE1)

Realizing its uniqueness as a tourist attraction and the possibility of increasing their income, there was a growing willingness to turn their products into 
something more visible and desirable. Strong motivations exist for performing such activities.

We also asked how the informants perceived the changes they were experiencing. Participants saw the process of innovation as necessary, particularly the lacemakers, and indicated that future projects existed for implementation or enhancement of these artifacts. For example, we mentioned a survey conducted with Fashion Designer students from Santa Catarina State University (UDESC). The records below were obtained from lacemakers.

[11] "So I think that if you diversify, if you begin to make practical things, really beautiful things [...] but if you keep on making only those small little towels, it's more complicated." (L.I6)

[11] "Então eu acho que se diversificar, se começar a fazer coisa práticas, coisa bonitas mesmo [...] mas se continuar fazendo só a toalhinha é mais complicado." (L.I6)

[12] "So this whole idea of doing the full job here, so that's the way we'd like it to be in the future We'd like to have a team here where one part would do the design, the lacemakers would make the lace parts and the seamstresses would assemble the parts, and produce something different, something contemporary [...] without forgetting about the reference craft." (A.I4)

[12] "Então a ideia toda essa, a gente ter um trabalho completo aqui, então a gente gostaria no futuro, de ter uma equipe aqui que tivéssemos uma parte de pessoas que fizessem o design, tem as renderias para fazer as peças e teríamos as costureiras pra montar as peças, assim fazer um produto diferenciado, contemporâneo [...] e não deixando de lado o artesanato de referência." (A.I4)

In contrast, one potter was not very happy with the changes; she said: [13] "There are some who now put goldfish on the lid [Or write] "Souvenir of Vitória", or the name of a customer who asks for it. I don't do that, I'm still true to the tradition." "Here we have the idea that the artifacts belong to the culture." She continued by saying "[...] so I really promote this culture, I can't say it in nice words, but I know it's very important and I will never abandon this culture." (C.I2)

[13] "Tem algumas paneleiras que agora colocam peixinho na tampa, né? escreve "lembrança de Vitória" nome de cliente que pedem, eu não, eu ainda estou firme na tradição.” (C.I2)
[...] "Aqui nós temos à ideia de que os artefatos pertencem a essa cultura. "[...] então, eu prego muito essa cultura, eu não tenho palavras bonitas pra falar, mas eu sei que ela é muito importante e que eu nunca vou deixar essa cultura." (C.I2)

\section{Creativity, skills, and motivation}

To another participant (C.I1), the incentive to continue her craft, beyond trading pottery, is also connected to the value attaches to it. Referring to tourists visiting the shed she said: "They are very fond of our work." The appreciation of the craft as well as a sense of cultural belonging is evident in the following statement:

[14] "[...] And we began to love our culture, we began to understand that we were part of this culture, from the time of our ancestors, our grandmothers, greatgrandmothers, their grandmothers, so we are really part and parcel of this culture." (P.E2)

[14] “[...] e começamos a ter amor por essa cultura, começamos a entender que nós fazíamos parte dessa cultura, desde os nossos antepassados, nossa vó, bisavó os avós deles, então nós somos integrados mesmo nessa cultura." (P.E2)

These participants stressed the importance of (a) self-perception of motivation to perform the task, and (b) initial level of intrinsic motivation related to the task as outlined by Amábile (1996). Traditionally, the collective work was based on the division of specific tasks that developed between men and women. Originally, men were responsible for 'heavier' work, such as fetching clay, removing the tannin in mangroves, and making the fire for firing the pottery. The women potters were responsible for molding and shaping the pots, but this aspect of the tradition is also changing. In the shed, there are men who make clay pots, who prefer to be called 'artisans'. Some women also fire their own pottery.

Historically, participating lacemakers reported that the men's job was to pick grass in the bush for cushion fill and provide carpentry services for making the pads and bobbin supports. Lace had a feminine meaning and significance (it was not men's work). However, currently, there are also men developing this skill. The process of workers reinventing themselves was embellished and lent a higher degree of meaning to their traditions. 


\section{Modernity, discourse elements}

In relation to the cultural spaces, "Paneleiras Shed" and "Big Lacemakers' House", both are currently promoting educational activities organized into "workshops". As the Coordinator of "Big Lacemakers' House" noted, activities are undertaken throughout the year, but with more frequency on school holidays and during the summer. In an informal manner (no set hours or activities, for example), interested parties can enroll and participate in activities together with the lacemakers to learn new skills.

However, there are also lacemakers periodically contracted by the Foundation with the specific intent of teaching the practice to others. The room where the lacemakers spend their Wednesdays, Thursdays and Fridays afternoons, and the place where learning activities and sharing occurs is rather simple and not very large. There is still, in the Big Lacemakers' House, space for exhibitions and selling the produced work.

Less than a year into operations, the new Paneleiras Shed, was built by the City of Vitoria with funds from the Ministry of Tourism. While designing the shed, special attention was paid to the creation of a space for the public (tourists, learners, onlookers). On the second floor the central room is open for the supervision of the entire process of firing. The process of cleaning and baking of pottery is done outdoors.

With the large influx of tourists, the "Paneleiras Association" envisions the possibility of more financial resources, well beyond tourism. For some participants (e.g., C.I1) the new shed met their expectations and they seemed to be proud of it. However, another participant stated that their ideas were not fully taken into consideration upon planning the construction. They considered the place very different from what they imagined, however they recognized the importance of this new space for commerce and a better approach to tourism.

[15] "[...] It's still the same, because if the rain comes with a strong blast of wind, it ruins all my pottery. We have a lot of needs here, a lot of problems." (C.I2)

[15] “[...] ainda continua do mesmo jeito, porque se vem uma chuva de vento, a chuva acaba com minhas panelas todinhas. Então tem muita falha, aqui, muito problema." (C.I2)

After identifying conflicts regarding the space and its physical structure, we posed the same question to the cultural agents of the two groups surveyed:

[16] "The idea of a reference center (Big Lacemakers' House) is to give a better dynamic to this whole process, so that we don't lose this traditional handcraft, this cultural reference because it tells part of our story."'(A.I4)

[16] "A ideia do centro de referência (Casarão das Rendeiras) é dar uma dinâmica melhor pra elas, pra todo esse processo, pra que não perdemos esse artesanato de tradição, de referência cultural porque conta parte de nossa história." (A.I4)

[17] "Look it's almost like feeling you've really done what you had to do because their work conditions were very precarious [...] and their production in the warehouse increased so much, but I just don't know if it was only because of the new, bigger space, or because the number of tourists increased dramatically." (A.I3)

[17] "Olha é quase um sentimento de dever cumprido mesmo, porque as situações de trabalho delas era precário mesmo [...] e a produção delas no galpão aumentou muito assim, e eu não sei só se pelo espaço novo e maior mesmo, ou pela frequência de turismo porque aumentou assustadoramente.” (A.I3)

In the two interviews with cultural agents, the political commitment of public institutions was observable, but their ideas are not always understood by the different actors involved. In other discussions, it was possible to observe opposing opinions. For example, one participant's somewhat 'romantic view' of building the shed:

[18] "Oh gosh! There's just no comparison! It's way more comfortable. Because in the past when it rained, and when there was a high tide, Oh God! it was pure mud inside the warehouse. We used to put down a pile of wooden boards to step over, we used to get so embarrassed when the tourists slipped. It was so serious! Oh my God! It was so awful! But not now, now we're in heaven. It's great." (C.I1)

[18] "Nossa, menina, nem compara! Tem mais conforto, tem. Porque antigamente era tudo assim, quando chovia, quando a maré enchia demais também, nossa mãe de Deus, ficava que era uma lameira dentro do galpão. A gente botava um monte de tábua pra pisar em cima, os turistas chegavam, a gente tinha vergonha, sério mesmo, chegavam a escorregar aqui, Ó Meu Deus do Céu!! Era coisa horrível, muito ruim mesmo. Agora não, agora nós estamos no paraíso. Muito bom." (C.I1)

Regarding the 'Big Lacemakers' House' one participant (L.15) stated: [19] "I come on Wednesdays, and on Fridays but on some Wednesdays and Fridays 
I don't come, I can't make it. I'm here with them all. In the summer, I don't come because I have a small shop. Then I come back here and spend an evening, and have a cup of coffee [...] there are jokes and all that and so it goes. Sometimes people come to film us, there are tourists and that's how it is. The director here is very dear to us." The importance of the Big House in providing social support for members of the community was evident.

[19] "Venho às quartas feiras, venho as sextas, tem sexta que eu não venho, quarta que eu não venho, assim. Eu to aqui com elas tudo, no verão eu não venho, porque eu tenho a lojinha, no outro, depois eu venho, passo a tarde aqui, a gente toma um cafezinho, pega de dizer palhaçada e tudo e vai passando, as vezes chega gente pra filmar a gente, turista, e vai passando. A diretora daqui é muito querida com a gente." (L.15)

Public policies regarding culture, such as actions organized and managed by the State, emerged in the 1950s. Since 1990, the relationship between culture and the economy has gained greater visibility. Currently, various institutions promote initiatives for cultural management. However, in many departments and foundations the CEO's job is politically appointed and occupied by a professional with no training in the artisan crafts sector.

In regards to the role of "cultural sponsorship", the Federal Government ensures State protection and custody over assets, development, promotion, and public policy through legislation. What we see, in general, is the outsourcing of the cultural sector to the private sector, via tax incentives.

The Federal Cultural Incentive (Law n. 8313 of December 23, 1991) or the "Rouanet Law" established public policies for the cultural sector. As highlighted in this law, the tax incentive policy enables both companies and individuals to apply a portion of their income tax towards cultural programs (Beaud and Weber, 2007).

The cultural policy-making must start from the perception of culture as a collective democratic good. The distribution of resources to Brazilian states should be based on this premise. Cultural heritage must be preserved, promoted and shared nationwide.

In this study we investigated issues related to the cultural identity of these populations and their relationship to modernity. Artifacts, originally developed for traditional uses, when in contact with the tourism industry, tend to become a representation, an imitation of the traditional object, a kitsch. A term proposed by the thinkers of the Frankfurt School, is art as an object of mass consumption (Felski, 1990).
Here, we define identity as the sense of belonging to a particular group or society. Identity is formed "in the interaction between self and society" (Hall, 2003, p. 11). We asked participants whether in this relationship between traditional knowledge and tourism, there was a loss of traditional cultural identity.

[20] "No, I don't believe there is any loss, in fact, I think it's the opposite, it as it were, helps us. I don't think we're losing our tradition, because there's no way it can be lost, because those who know it never lose it, isn't that right?" (A.I4)

[20] "Não, eu não acredito que haja perda não, eu acho que bem pelo contrário, isso vem até vamos dizer assim, a ajudar, eu acho que não vem a perder a tradição, porque não tem como perder, porque quem sabe fazer não perde de saber aquilo ali né?" (A.I4)

[21] "There will always be someone to do [traditional work].” (L.I5)

[21] "Sempre vai ter alguém que vai fazer...[trabalho tradicional]." (L.I5)

[22] "I really don't think so. As they get to know each other [...] they feel much stronger. And the increase in sales, the direct relationship that they see, that's not possible. [...] I think that's where it is. As soon as they begin to recognize their own worth there is no reason to give up. I think that the cultural identity gets stronger, $[\ldots]$ as they preserve it." (A.I3)

[22] “[...] sinceramente não. À medida que elas se reconhecem [...] elas se sentem mais fortes mesmo sabe? E o crescimento das vendas, relação direta que elas veem, não é possível sabe [...] acho que ta ai mesmo. A partir do momento que elas se valorizam não tem porque acabar, acho que cada vez a identidade cultural fica mais forte, na medida que elas vão preservar isso." (A.I3)

There is a clear contradiction in the statements above. The managers see the current process as a factor of permanence, a process that is strengthening traditional populations. However, the statements of participants like C.I1 and C.I.2, below, indicate disruptions to the dynamics of the traditional knowledge change process and hence in the tradition, because the continuity of the activity in the nuclear family is what kept this tradition alive.

[23] "My kids make them, if you ask them to, they make pottery, some small pots maybe? But now they don't have time for making pottery. But if they are asked to, they make them." (C.I1) 
[23] "Meus filhos fazem, se mandar fazer panela, eles fazem, alguma panelinha pequena né? Mas agora eles não tem tempo de fazer panela, né? Mas eles fazem, se mandar, eles fazem." (C.I1)

[24] "My children are not interested, but they respect the work [...] children of pot makers don't want to make pottery, but with time, if we don't find people who want to make pottery, people who want to be part of this milieu, [...] it will disappear." (C.I2)

[24] "Meus filhos não se interessam, mas eles respeitam [...] filho de paneleira não querem, então, vai com tempo, se não surgir outras pessoas, que queira fazer panelas, que nós queiramos integrar no nosso meio [...] vai acabar.” (C.I2)

Among the participants, there are still those who see the negative impact of modern society on traditional practices. In the lacemakers case, one participant (L.I5) did not approve of people from other states or countries, learning the craft: it seems [25] "as for me, I feel that lace had more value in the beginning when these people didn't come here to make lace [...] because people come from São Paulo, Rio, from Curitiba. They come from all these places to learn. So at that time our lace had more value."

[25] “[...] eu já pra mim, que a nossa renda tinha mais valor no princípio, quando essa gente não vinha pra cá pra fazer renda, porque vem gente de São Paulo, do Rio, vem de Curitiba, vem de tudo aprender, né? Então aí a nossa renda tinha mais valor.” (L.I5)

This issue was also problematic for C.I2. [26] "because in fact many pot makers don't like outsiders coming here to make pottery, and if they don't come what will happen? If our own generation doesn't really want this work? And really our generation doesn't want it." One can see that while L.I5 believes that sharing traditional knowledge with other cultures devalues his legacy, C.I2 sees it as a somewhat natural progression with the possibility of continuity.

[26] “"...] porque na realidade, muitas paneleiras não gostam que vem pessoas de fora, fazer aqui e se não vier, como é que vai ficar? Se a nossa geração mesmo não quer? A nossa geração não quer.” (C.I2)

According to Codo (2002, p. 302), the social identity of the individual is built from a feeling of belonging, a mirroring process along with individual development. By belonging this author indicated that there is a relationship "where one identity is made upon the identity of the other."11 This notion is explicit in this participant's response:

[27] "IPHAN was always having meetings and putting it in our heads that we were an immaterial heritage, that we were important, only you have this art of making pottery, there are a lot that looks like you, but nothing equal to you. Ok, but I didn't go along with that $[. .$.$] One time [...] a guy involved with$ capoeira (Brazilian martial art) got talking to me, saying that he was immaterial heritage that he was important, he was part of the country's culture. He said so many beautiful things that I took it to heart, and from then on it sunk in. Yes, [...] I'm cultural heritage, pottery is cultural heritage. IPHAN was always saying that, trying to convince me, but what made it take root, what gave me the desire to take care of my work was when I talked to that young guy. So now I really promote this culture, I can't say it in fancy words, but I know it's very important and that I will never give up this culture." (C.I2)

[27] "Aí, o IPHAN sempre fazia reuniões e ia botando na nossa cabeça, vocês são bem imaterial, vocês são importantes, só vocês que tem essa arte de fazer panela, tem muitos parecido, mas não igual a de vocês. Tá, mas isso daí não ficou muito em mim. Foi uma vez [...] um moço que é da capoeira, ele começou a conversar comigo, assim, começou falar que ele era bem imaterial, que ele era importante, que ele era cultura do país. Ele falou tanta coisa bonita que aquilo lá brotou mesmo no meu coração, daí em diante, aquilo ficou firme no meu coração: é... eu sou patrimônio cultural, paneleira é patrimônio. O IPHAN sempre colocou aquilo, colocou no coração, só que quem fez ela brota mesmo, crescer esse desejo de cuidar do meu trabalho, foi quando eu conversei com aquele moço. Então, eu prego muito essa cultura, eu não tenho palavras bonitas pra falar, mas eu sei que ela é muito importante e que eu nunca vou deixar essa cultura." (C.I2)

This participant (C.12) recognized himself through the interaction within the group. Individual identity is established especially in relationships where there is an exchange of values as explained by C.I2: [28] "My kids have their own little things, what I can afford, my children are studying, the school material is bought with the money I earn making pottery". The identity and tradition are historically situated and anchored in the ways of survival, "to the extent that they expand the horizons of exchange: within a group, drawing and mirroring between groups, drawing the belongingness with the whole 
society, defining modern individuality" (Codo, 2002, p. 303). ${ }^{12}$

[28] "Meus filhos tem as coisinhas deles, o que eu posso comprar, meus filhos estudam, material de escola é comprado com dinheiro da panela que eu faço." (C.12)

\section{Final Considerations}

The interaction between new and traditional methods leads some people to the development of different forms of creativity and incremental innovations, in a reinvention of their work. People need the programmed knowledge they have acquired over the years, but in the rapidly changing conditions in which we live today, it is not enough for survival (Bergman et al., 2012).

In scenarios like tourist centers, this interaction is markedly higher. Traditional populations and their artifacts are no longer anonymous they are able to survive in the face of modern influences. Tourism development in traditional communities brings both benefits and losses to local residents and to the very organization of the community. Tourism can promote ways of strengthening the traditions and promoting local distinctiveness. By providing contact with other cultures, local actors create possibilities to broaden their worldview. However, other activities such as tourism trade, for example, instigate cultural changes that may act on the knowledge generated by local tradition, focusing on exactly what attracts the tourists; singularity.

\section{References}

ALENCAR, E. M. L. S.; FLEITH, D. de S. Contribuições teóricas recentes ao estudo da criatividade. Psicologia: Teoria e Pesquisa, v. 19, n. 1, p. 1-8, 2003.

ALEXANDER, M.; CHAMUNDEESWARL, K.; KAMBU, A.; RUIZ, M.; TOBIN, B. The role of registers and databases in the protection of traditional knowledge: a comparative analysis. Tokyo: United Nations University/ Institute of Advanced Studies, 2004.

AMÁBILE, T. M. The social psychology of creativity. New York: Springer-Verlag, 1983.

Growing up creative. Buffalo, NY: The Creative Education Foundation, 1989.

Creativity in context. Colorado: Westriew
In conclusion, some similarities and contrasts between the two sets of survey results (pottery and bobbin lacemakers) are as follows:

- Both groups followed a pattern of informal learning of their crafts;

- Both groups relied on Municipal Public Policies;

- Both groups experienced exploitation by the tourist industry;

- The Big Lacemakers' House is a cultural action driven by a search for current markets, while in "Paneleiras Goiabeiras" this goal was previously attained;

- The "Paneleiras Shed" served as a planning space, specifically organized where all potters trade their pans, while the Big Lacemakers' House was considered a space of reference, and continues to be, in the "Lagoa da Conceição" district, "Rendeiras" (lacemakers)" street, and various craft shops;

- The "Paneleiras Goiabeiras Association" mediates between artisans and external entities, regulates and standardizes routine activities and the commercialization of pottery;

- It is clear, as noted by the discourse of the Big Lacemakers' House manager, that the objective was to adjust the cultural goals of the place to PROMOART.

It is also worth noting that these findings are only a portion of the studied context. Traditional cultural artifacts should be analyzed in their historical, social and economic dimensions. In addition, such activities must meet local developmental objectives, a strategic alternative for economic growth in certain localities. The same approach is recommended upon undertaking surveys of similar populations.

ARRUDA, R. "Populações tradicionais" e a proteção dos recursos naturais em unidades de conservação. Ambiente $\mathcal{E}$ Sociedade, v. 2, n. 5, p. 79-92, 1999.

ASSOCIAÇÃO DAS PANELEIRAS DE GOIABEIRAS. Disponível em: http://www.turismocapixaba.com.br/ espirito-santo/associacao-das-paneleiras-de goiabeiras\#. Uqr4-Ces_Sg. Acesso em: jul. 2013.

BEAUD, S.; WEBER, F. Guia para a pesquisa de campo: produzir e analisar dados etnográficos. Petrópolis, RJ: Vozes, 2007.

BENJAMIN, R. A fala e o gesto: ensaios de folk comunicação sobre narrativas populares. Recife: Imprensa Universitária, 1996.

Press, 1996.

12. Tradução dos autores, do original: "na medida em que se ampliam os horizontes de troca: dentro de um grupo, desenhando o espelhamento, entre grupos, desenhando o pertencimento, com toda a sociedade, definindo a individualidade moderna" (Codo, 2002, p. 303). 
BERGMAN, P.N.; AHLBERG, G.; JOHANSSON, G.; STOETZER, U.; ÁBORG, C.; HALLSTEN, L.; LUNDBERG, I. Do job demands and job control affect problem-solving? Work, v. 42, p. 195-203, 2012.

BRAHY, Nicolas. The contribution of databases and costumary law to the protection of traditional knowledge. International Social Science Journal, v. 58, n. 188, p. 259-282, 2006.

BRASIL. Decreto n. 6.040, de 7 de fevereiro de 2007. Institui a Política Nacional de Desenvolvimento Sustentável dos Povos e Comunidades Tradicionais. Diário Oficial [da] República Federativa do Brasil. 2007. Disponível em: http:// www.planalto.gov.br/ccivil_03/_Ato2004.2006/2004/ Decreto/D5051.htm. Acesso em: ago. 2012.

BUSINGYE, J.; KEIM, W. The political battlefield: negotiating space to protect indigenous and traditional knowledge under capitalism. International Social Science Journal, v. 60, n. 195, p. 37-54, 2009.

BRUCE, M.; BESSANT, J. Design in business: strategic innovation through design. Harlow: Pearson Education Limited, 2002.

CANCLINI, N. G. Culturas híbridas. São Paulo: EDUSP, 2003.

Consumidores e cidadão: conflitos multiculturais da globalização. Rio de Janeiro: Editora UFRJ, 2005.

CARVAlHO, J. J. As duas faces da tradição: o clássico e o popular na modernidade latino-americana. Brasília: Universidade de Brasília/Instituto de Ciências Humanas, 1991. 28p.

CASTRO, E. Território, biodiversidade e saberes de populações tradicionais. Belém: Núcleo de Altos Estudos Amazônicos, 1998. 16p.

CODO, W. Identidade e economia (I): espelhamento, pertencimento, individualidade. Psicologia: Teoria $e$ Pesquisa, v. 18, n. 3, p. 297-304, 2002.

Comissão Econômica para a América Latina e o Caribe. Inovar para crescer: desafios e oportunidades para o desenvolvimento sustentável e inclusivo na IberoAmérica. Santiago do Chile, 2009. Disponível em: http:// www.innovalatino.org. Acesso em: set. 2012.

CRESWELL, J. Projeto de pesquisa: métodos qualitativo, quantitativo e misto. Porto Alegre: Artmed, 2010.

CUCHE, D. A noção de cultura nas ciências sociais. Bauru: EDUSC, 1999.

FELSKI, R. Kitsch, romance fiction and male paranoia: Stephen King meets the Frankfurt School'. The Australian Journal of Media \& Culture, v. 4, n. 1, 1990.
FREEMAN, C.; PÉREZ, C. Structural crises of adjustment, business cycles and investment behavior, technical change and economictheory. Londres: Pinter Publisher, 1988.

GIDDENS, A. As consequências da modernidade. São Paulo: Ed. UNESP, 1991.

GIL, A.C. Como elaborar projetos de pesquisa. São Paulo: Atlas, 2010.

HALL, S.A. Identidade cultural na pós-modernidade. Rio de Janeiro: DP\&A, 2003.

HOBSBAWM, E. R. T; RANGER, T. (Orgs.). A invenção das tradições. Rio de Janeiro: Paz e Terra, 1984.

KOTHARI, A. Traditional knowledge and sustainable development: draft for discussion. Winnipeg: International Institute for Sustainable Development, 2007. 11p.

KUMARI, J. Indigenous knowledge erosion. Indian Folklife, v. 2, n. 4, p. 10-11, 2003.

MARQUES, E. Folclore, turismo e mídia: tradição e modernidade. In: CONGRESSO BRASILEIRO DE FOLCLORE, 10, 2004, São Luiz, Comissão Maranhense de Folclore: $10^{\circ}$ Congresso Brasileiro de Folclore. São Luiz: Mundicarmo Ferretti (CMF), 2004. p. 30-39.

MOREIRA, E. Conhecimento tradicional e a proteção. TEC Amazônia, v. 5, n. 11, p. 33-40, 2007.

PERRELLI, M. A. de S. Conhecimento tradicional e currículo multicultural: notas com base em uma experiência com estudantes indígenas Kaiowá/Guarani. Ciência \& Educação, v. 14, n. 3, p. 381-396, 2008.

POPADIUK, S. C. C. Innovation and knowledge creation: how are these concepts related? International Journal of Information Management, v. 26, n. 4, p. 302-312, 2006.

PROMOART. Disponível em: http:// fundacaofranklincascaes.blogspot.com.br. Acesso em: jul. 2013.

SIMANTOB, M.; LIPPI, R. Guia valor econômico de inovação nas empresas. São Paulo: Globo, 2003.

SUKULA, S.K. Developing indigenous knowledge databases in India. The Electronic Library, v. 21, n. 1, p. 8393, 2006.

TAYLOR, S. J.; BOGDAN, R. Introduction to qualitative research methods: a guidebook and resource. New York: John Wiley \& Sons, 1997.

UNESCO. United Nations Educational, Scientific and Cultural Organization. Convenção para a salvaguarda do Patrimônio Cultural Imaterial. Brasília, 2010. Disponível em: http://www.unesco.org.br. Acesso em: out. 2013. 


\section{Conhecimento tradicional e processos de inovação e criatividade: paneleiras e rendeiras de bilro brasileiras}

\section{Resumo}

Com uma abordagem qualitativa, este artigo tem o objetivo de esclarecer como aspectos de inovação e criatividade estão modificando os costumes de pessoas de duas comunidades tradicionais brasileiras: as paneleiras de Goiabeiras, da cidade de Vitória-ES, e as rendeiras de bilro, da cidade de Florianópolis-SC. Foram utilizados dados primários de observação e entrevistas semiabertas com paneleiras, rendeiras e agentes de instituições públicas, responsáveis pelos projetos nas comunidades, além de fontes de dados secundários, por meio da análise de documentos digitais (websites). Para a análise dos dados, a pesquisa utiliza a triangulação metodológica a partir de duas categorias: a tradição (sua manutenção) e os recursos e a inovação (seus elementos de discurso). O estudo mostra que essas pessoas, para permanecer em suas comunidades, usam o conhecimento de seus ancestrais e criam estratégias sustentáveis de subsistência e de geração de renda.

Palavras-chave: artefatos culturais, geração de renda, preservação do conhecimento, populações tradicionais, conhecimento tradicional.

\section{Conocimiento tradicional y procesos de innovación y creatividad: alfareros artesanales y creadores del encaje brasileño}

\section{Resumen}

Con un enfoque cualitativo, este estudio tiene como objetivo entender cómo los aspectos de la innovación y la creatividad están cambiando tradiciones. Miembros de dos comunidades tradicionales de Brasil participaron en este estudio, 'paneleiras de Goiabeiras' de la ciudad de Vitória, estado de Espírito Santo y 'rendeiras de bilros' de Florianópolis, estado de Santa Catarina. Fueron utilizados datos primarios de observación y entrevistas semiabiertas con alfareros, encajeras y agentes de las instituciones públicas, responsables por los proyectos en las comunidades, además de fuentes de datos secundarias a través del análisis de los documentos digitales (sitios web). Para analizar los datos, la investigación utiliza la triangulación metodológica a partir de dos categorías: la tradición (su mantenimiento) y los recursos y la innovación (sus elementos de discurso). El estudio muestra que estas personas están encontrando maneras de permanecer en sus comunidades, mediante el conocimiento de sus antepasados, y que crean estrategias de medios de vida sostenibles y de generación de ingresos.

Palabras clave: artefactos culturales, generación de beneficios, preservación de conocimientos, poblaciones tradicionales, conocimientos tradicionales. 